\title{
Da Lógica do Favor à Lógica do Pavor: um ensaio sobre a Geografia da violência na cidade do Rio de Janeiro
}

\author{
Carlos Walter Porto-Gonçalves
}

Universidade Federal Fluminense, Rio de Janeiro, Brasil. Email: cwpg@uol.com.br

\section{Rodrigo Torquato da Silva}

Universidade Federal Fluminense, Angra dos Reis, Brasil. Email: torquatopros@hotmail.com

Resumo: O presente artigo trata da geografia da violência urbana na cidade do Rio de Janeiro. Mostra como a ação do Estado está permeada por ignorâncias acerca das lógicas de experiências espaciais com que se organizam e operam as classes populares trabalhadoras do Rio de Janeiro. O objetivo é estimular uma discussão que impulsione as análises para além dos discursos estigmatizadores com relação à população favelada. A metodologia adotada assemelha-se às sinuosidades dos becos e vielas, visto que optamos em nos entranhar empiricamente na concretude do espaço favelado e, também, nas re-leituras das narrativas marginalizadas, dos compositores que há décadas oferecem pistas para que possamos esboçar um mapeamento das lógicas de sociabilidades e das experiências de espaço dessa população. Assim, podemos afirmar - ainda que hipoteticamente - que os mecanismos convencionais de análises e os instrumentos metodológicos fundamentados no distanciamento dos seus “objetos” são insuficientes para uma mínima compreensão do que se passa nos cotidianos de opressão e resistências das classes populares. O máximo que se tem alcançado historicamente, tanto com as pesquisas quantitativas acerca do tema quanto com os apelos midiáticos, é a forte influência na construção de discursos universalistas que naturalizam a criminalização dos citadinos mais pobres e as suas lógicas de integraçãosobrevivência nas cidades.

Palavras-chave: Favela, Território, Territorialidades e Violência urbana.

\section{De la lógica del favor a la lógica del pavor: un ensayo sobre la geografía de la violencia en la ciudad de Río de Janeiro}

Resumen: Este artículo trata de la geografía de la violencia urbana en la ciudad de Río de Janeiro. Muestra cómo la acción del Estado ha sido impregnada por la ignorancia acerca de la lógica de experiencias espaciales con la cual se organizan y funcionan las clases populares en Río de Janeiro. El objetivo es estimular un debate que promueva un análisis diferente de los discursos estigmatizadores con relación a la población favelada (chabolista). La metodología se asemeja a las sinuosidades de los callejones y callejuelas, ya que hemos elegido introducirnos empíricamente en la realidad del espacio favelado y, también, en las relecturas de relatos marginados de los compositores de música popular, que desde hace décadas nos ofrecen pistas para que podamos esbozar una 
representación de las lógicas de sociabilidades y de las experiencias de espacio en esa población. Por lo tanto, podemos afirmar -aunque hipotéticamente- que los mecanismos convencionales de análisis y las herramientas metodológicas basadas en la distancia respecto de sus «objetos» son insuficientes para una mínima comprensión de lo que sucede en el cotidiano de opresión y en la resistencia de los pobladores. Lo más que se ha logrado, históricamente, tanto en la investigación cuantitativa sobre el tema cuanto con los reclamos de los medios de comunicación, es una fuerte influencia en la construcción de discursos universalistas que naturalizan la criminalización de los habitantes más pobres de las ciudades y de su lógica de integración-supervivencia en las ciudades.

Palabras clave: Favela, territorio, territorialidades y violencia urbana.

\title{
From the logic of favor to the logic of horror: an essay on the geography of violence in the city of Rio de Janeiro
}

\begin{abstract}
The present article addresses the geography of urban violence in the city of Rio de Janeiro, Brazil. It shows how State action is apart from the logic of spatial experiences through which Rio's popular working classes work and get organized. The goal is to stimulate a discussion that could reach beyond the stigmatizing discourses related to the slums population. The adopted methodology resembles the curves of the slum's alleys and lanes as an option for us to drop empirically in the concretude of the slum's space. It is also a way to revisit the marginalized narratives of lyrics composers who have, for decades, given many clues for mapping the socialization logics and spatial experiences of the studied population. Historically, the appeals of the mainstream media such as the quantitative research have influenced the construct of a universalist speech that naturalizes the criminalization of the poorest and their ways of integration/surviving in the cities. Thus, we can say -even though hypothetically- that the convencional mechanisms of analysis and methodological tools based on the distance of their «objects» are insufficient for a minimal understanding of what goes on in everyday oppression and resistance of the working classes.
\end{abstract}

Key words: slum, territory, territorialities and urban violence.

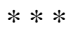

\section{Introdução}

A reflexão que segue se fez a partir dos acontecimentos que o Rio de Janeiro viveu nos últimos dez dias de novembro de 2010 quando o estado promoveu a maior operação militar-midiática que se tem notícia em nome do combate ao tráfico de drogas com todas as implicações de violência material e simbólica que esses eventos trazem. Impõe-se uma séria reflexão não só a nós intelectuais por profissão, mas a toda sociedade diante da expectativa $^{1}$ gerada de extermínio de jovens favelados, ainda que em situação de delinqüência ${ }^{2} \mathrm{O}$ que nos propomos nesse artigo é fazer uma análise da geografia da violência na cidade do Rio de Janeiro entendendo essa geografia da violência em suas múltiplas dimensões social, cultural e política. Acreditamos que, assim, estaremos contribuindo para superar uma visão que, infelizmente parece tomar conta do debate, onde a gravidade do 
problema acaba impondo uma urgência que longe de contribuir para sua superação, contribui para perpetuá-la. Não há solução imediata para esse problema complexo. Na análise que segue e pelo escopo teórico-político adotado procuramos nos aproximar do olhar com que os grupos subalternizados oferecem sobre a questão. E esse olhar, muitas vezes do alto de uma favela, é bem diferente daquele que Hanna Arendt chamou de "olhar de sobrevôo", posto que trata de um olhar bem "pé no chão" daqueles grupos sociais que conformam os espaços das favelas que os conformam.

O comandante-geral da Polícia Militar, Major Mario Sergio Duarte, disse explicitamente, no que foi repetido por todas as pessoas do alto comando da mega-operação na Vila Cruzeiro e no Complexo do Alemão, "que se tratava de retirar os bandidos de sua área de conforto, retirar o território". Aqui o conceito de território é trazido para seu cerne epistêmico, qual seja, o sentido de relações de poder nele implicado ${ }^{3}$. Afinal, quem controla o pedaço? Quem controla o espaço, seus recursos, suas gentes? "Todo espaço definido e delimitado por e a partir de relações de poder é um território, do quarteirão territorializado por uma gangue de jovens até o bloco constituído pelos países - membros da OTAN” (SOUZA, 2006, p. 111).

Nesse sentido, o conceito de território implica fronts, em linguagem militar, área em disputa, e definida a luta no front, o front torna-se fronteira com limites demarcados no espaço. Assim, os espaços vão sendo grafados, geografados e, deste modo, a geografia se mostra verbo, ação de sujeitos/ grupos sociais em relação (Porto-Gonçalves, 2001), em conflito, em confronto pelo espaço, através do espaço por meio de seus recursos materiais e simbólicos que, sabemos, não são distribuídos igualmente entre os contendores.

Mas, atenção: se a fronteira implica que o front está definido, essa definição implica limites e limites é a essência da política para os gregos, sendo que daí deriva a palavra polis ${ }^{4}$. Se o confronto implica o exercício da força para definir o controle do espaço, o domínio do território, o fim do confronto implica a política e aí é de outro campo que se trata, onde o uso da força deve ficar de fora. Afinal, o uso da força, da violência, é a negação da política (Arendt, 1981).

Falar em domínio do território é falar, portanto, de uma parte do problema. Todavia, não há território sem territorialidade, não há território sem que tenha havido um processo de territorialização. Enfim, é a tríade território-territorialidade-territorialização que há de ser compreendida. A territorialidade está configurada por um conjunto de relações materiais e simbólicas que emprestam sentido à constituição/construção/produção/ invenção/criação de um determinado espaço. Assim, não há território/ territorialidade que não tenha sido obra da sociedade fazendo história por meio do espaço, se geografizando.

A expressão Complexo do Alemão dá idéia do não-conhecimento pelo saber instituído do espaço em questão. Isso não quer dizer que não 
seja um espaço conhecido. Afinal, no próprio processo histórico de ocupação daquele espaço os grupos sociais que o fazem sabem o espaço no sentido concreto de todo saber, qual seja, experimentando-o e a partir daí elaborando suas práticas de construção de casas, de caminhos, enfim, da invenção da existência quase sempre em lugares desvalorizados pelo capital/pela sociedade, haja vista serem grupos sociais desvalorizados por essa mesma sociedade. Com freqüência esses espaços são espaços bastante acidentados, ou áreas alagadas, ou áreas de mangues, ou áreas de matas nas periferias urbanas que, com a magnitude do processo de urbanização dos últimos 40 anos, muitas delas estão hoje abarcadas pelo entorno urbano, ainda que sendo marginais e periféricas tal e como são sentidas/percibidas por essa mesma sociedade/por seus diferentes grupos sociais. Enfim, para além do território que a polícia visava tomar com essa mega-operação há outras lógicas territoriais que precisam ser compreendidas.

\section{Breve nota teórico-conceitual}

Para entrarmos nessa seara analítica optamos por um diálogo empíricoreflexivo como metodologia de análise. Empírico-reflexiva porque na produção deste artigo estão dois sujeitos com experiências de territorialidades distintas, porém confluentes, na medida em que se trata de sujeitos conformados a partir de origens sociais de famílias pobres, forjados em bairros pobres, inclusive em favelas, e que tiveram acesso à formação acadêmica em toda sua extensão. E aqui se impõe, ainda que sucintamente, a explicitação do lugar de enunciação dos autores desse artigo, posto que não são reflexões distanciadas, mas de saberes territorializados.

Sabemos também que sendo esses espaços onde forjamos as nossas subjetividades espaços contraditórios muitas são as falas que dele podem emanar. Portanto, não se trata da única fala possível, nem do discurso verdadeiro acerca dessas territorialidades, mas que se trata de uma reflexão que se nutrindo da tradição do pensamento crítico acadêmico se vale também de outras matrizes de racionalidade advindas da experiência (Thompson, 1987 [1963]), enfim, há um diálogo de saberes implicado no nosso próprio conhecimento que se faz com e não sobre esses espaços.

\section{Sobre o processo de territorialização}

São complexos os processos que ensejam a conformação territorial de nossas cidades, sobretudo quando entendemos o processo de conformação territorial com todo o rigor conceitual que merece. Como costumava afirmar o geógrafo Milton Santos (Santos, 1982), “o espaço é acumulação desigual de tempos”, lugar da “contemporaneidade do não-coetâneo” (Paiva, 2000). O espaço sempre abriga tempos de distintas durações e múltiplas temporalidades.

A cidade do Rio de Janeiro, apesar das suas singularidades e particularidades, abriga em seu seio um padrão de poder típico da sociedade 
brasileira que bem pode ser caracterizado pela imagem ao mesmo tempo sociológica e espacial que nos foi dada por Gilberto Freire. Afinal, nossas cidades se caracterizam como reprodução ampliada da Casa Grande e Senzala.

\section{As Duas Faces de uma Mesma Cidade}

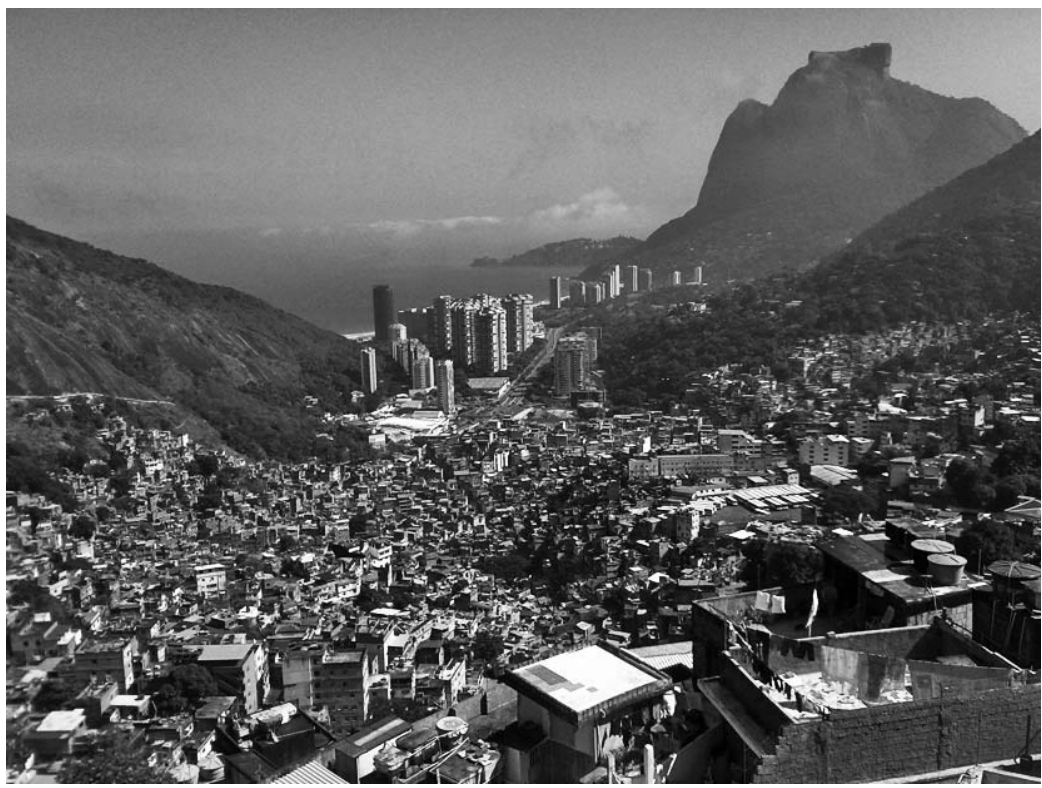

Os prédios ao fundo são do bairro de São Conrado, um dos bairros mais ricos da cidade do Rio de Janeiro, na perspectiva da Rocinha.

Foto: Rodrigo Torquato da Silva

A geografia física do Rio de Janeiro, cidade cujo sítio se encaixa Numa baixada ao largo de uma baía onde deságuam rios de pequena extensão que descem de vales de um maciço cristalino cujos pães de açúcar são a expressão de uma estrutura geológica antiga desnudada pela erosão, foi ocupada por essa sociedade desigual. De início, sabemos, as oligarquias preferiram ocupar a parte alta, livre do mau-cheiro e dos mosquitos, e deixaram os mangues para os pobres. Santa Tereza, São Cristóvão e o Alto da Boa Vista (Tijuca) foram espaços de elite. Durante muito tempo, a zona do baixo meretrício foi o bairro do Mangue, na baixada em torno da Praça da Bandeira onde hoje está um centro administrativo da prefeitura que a população chama por Piranhão, atualizando a memória daquele espaço.

Não ignoremos que em muitas áreas do espaço que hoje é recoberto pela cidade do Rio de Janeiro foram ocupadas por comunidades negras 
seja à época da escravidão, seja como estratégia de sobrevivência numa sociedade que abolindo a escravidão não democratizou o acesso à terra e ainda quis fazer a higienização/branqueamento, o que significa dizer que a abolição da escravatura não se deu pelo amor à liberdade e aos negros, mas "para inglês ver"5.

Além das florestas do Andaraí e da Tijuca, que eram conhecidas por abrigarem grupos de quilombolas desde o final do século XVIII, outros estudos apontaram também outras freguesias. Em um relato de 1826, diz-se que 137 escravos foram presos no distrito da Lagoa (atual Lagoa Rodrigo de Freitas), sendo provavelmente o local de considerável quilombo, dadas as condições físicas da região. Inhaúma, Irajá e Engenho Velho também eram zonas de quilombos (...). (Campos, 2005: 35).

A Serrinha, no bairro de Madureira ${ }^{6}$, a Comunidade dos Silva no Sacopã, a Rocinha ${ }^{7}$, o Estácio e todo o conjunto de favelas que dali se une com a Tijuca ${ }^{8}$ são exemplos dessa presença negra enquanto espaço de resistência. O racismo é um componente importante do nosso processo de conformação territorial.

As fotos abaixo confirmam a presença do povo negro na favela da Rocinha. Trata-se de um antigo casarão-armazém, construído sob paredes de pedras, de propriedade de um antigo patriarca negro, o Sr. Cesário da Rua Um, no início do século XX.
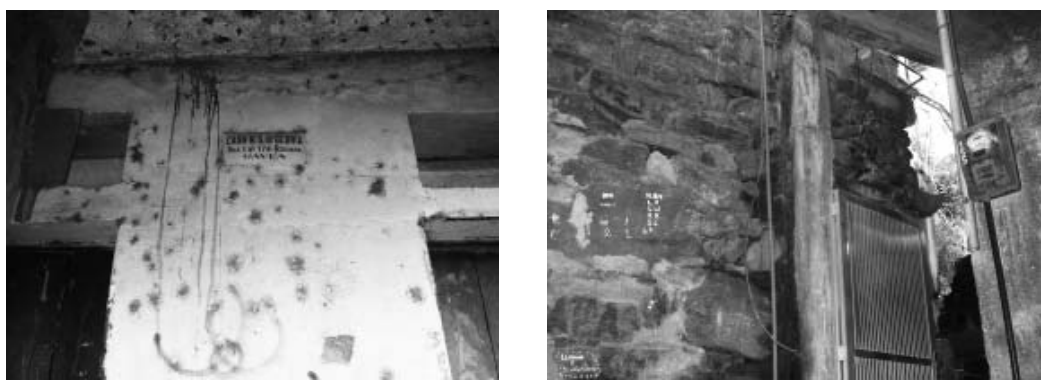

Fotos: Rodrigo Torquato da Silva

Com as migrações que se intensificam com a interligação do espaço brasileiro, sobretudo após a abertura da Rodovia Rio-Bahia nos anos 1930, uma vaga de migrantes nordestinos veio se juntar aos pobres urbanos "quase todos pretos” que por aqui já existiam. O preconceito de classe é, sempre, culturalmente moldado e o preconceito racial se recobriu como preconceito aos "Paraíbas”, aos “cabeças chatas”, aos “paus-de-arara”.

Os nordestinos inventaram seus espaços de resistência e afirmação identitária tanto no interior das comunidades ${ }^{9}$ com suas complexas redes de parentesco e ajuda mútua, como na grande feira de São Cristóvão. 
Todavia, o quadro geral do que chamamos reprodução ampliada do padrão de poder Casa Grande e Senzala se impôs quando vemos que entre a Urca e Copacabana, temos a favela do morro do Chapéu Mangueira; entre Copacabana e Ipanema, a do Pavão/Pavãozinho; entre o Leblon/Gávea e São Conrado, as favelas do Vidigal e da Rocinha e ao largo da cidade, numa escala mais ampla, todo o eixo da Avenida Brasil e da Zona da Leopoldina, tradicionalmente bairros proletários onde está o Complexo do Alemão e a Vila Cruzeiro, são ocupados por imensas favelas desde os anos 1950, de onde saem a maior parte dos trabalhadores da cidade, assim como da Zona da Central (Méier, Cascadura, Engenho de Dentro, Madureira). Esse complexo urbano não pode ser compreendido sem o Grande Rio, a Baixada Fluminense e São Gonçalo, principalmente, que tiveram o mesmo destino aqui apontado da Zona da Central e da Leopoldina, que é como os cariocas identificavam as regiões da cidade ${ }^{10}$.
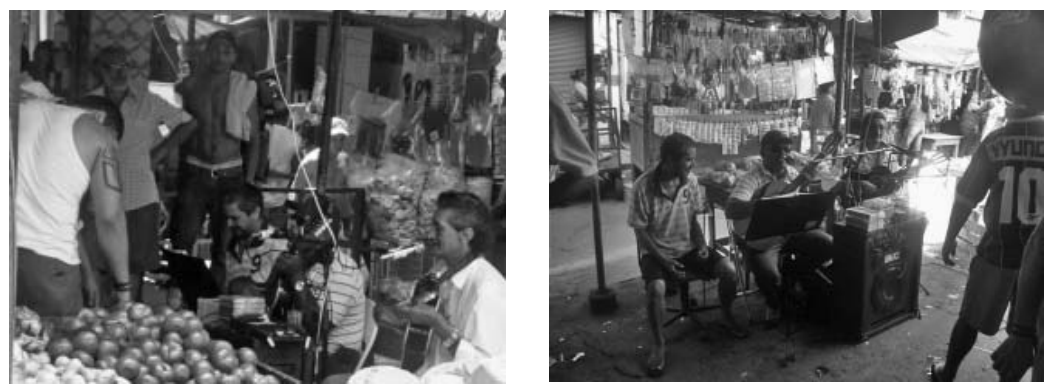

Há uma relação intensa entre esses espaços tão desiguais, como sempre houve entre os quilombos e os espaços circundantes onde, por exemplo, sempre se podia fazer "um ganho", prestar algum serviço e obter outro tipo de ganho e, ao mesmo, estar sempre alerta para libertar outros presos, à época, escravos. Era comum que aqueles que cometiam algum delito, fossem negros ou não, buscasse refúgio nesses espaços que, assim, conforma outros valores, outras relações sociais e de poder. Assim também é hoje e isso tem importantes implicações para a economia política da favela como parte da sua territorialidade, conforme veremos.

Entre grupos sociais subalternizados se conformando e conformando espaços próprios e ainda sem escolaridade formal é comum o respeito à palavra" $^{11}$ o "sujeito-homem de que nos fala o historiador Marcos Alvito (Alvito, 2001). Entre as comunidades negras, por exemplo, a reverência aos mais velhos é comum ainda hoje, seja nos pagodes, seja nas Velhas Guardas ou nas alas das baianas das escolas de samba. Talvez a figura de Pixinguinha seja a melhor expressão dessa reverência.

Sabemos que a sociedade brasileira é marcada por relações sociais de poder patrimonialistas onde o poder tem dono. "Os Donos do Poder", na feliz expressão de Raimundo Faoro, onde a lógica do favor se impõe à 
lógica do direito. E foram essas relações não-republicanas que conformaram a reconfiguração geográfica da sociedade brasileira com a intensificação do processo de des-ruralização e sub-urbanização acima indicado. Voltaremos a esse tema mais adiante.

Especificamente na cidade do Rio de Janeiro essas relações sociais e de poder ensejaram um tipo próprio que, pela condição de capital federal da cidade até o ano de 1960, chegou a ser um personagem nacional: o "malandro carioca". Visão romântica do homem cordial à carioca que olvidava o caráter profundamente autoritário implicado nessas relações sociais e de poder do "aos amigos tudo, aos inimigos a lei", onde também está presente "o sabe com quem está falando?” e o "ponha-se no seu lugar!”. A figura do "malandro carioca” é irmã de outra que lhe é contemporânea, a do pelego ${ }^{12} 14$, qual seja, aquele que se coloca entre os "de cima” e os “de baixo" para que os "de cima” permaneçam em cima e os “de baixo” permaneçam em baixo, mas com uma pele para que ninguém se machuque.

O final dos anos cinqüenta veria um dos melhores encontros desse processo de urbanização do país, particularmente no encontro das classes médias da Tijuca e da Zona Sul com as camadas proletarizadas das favelas e da Zona Norte com o fenômeno da bossa nova, do qual a cidade do Rio de Janeiro foi protagonista. O encontro de Vinicius de Morais com Pixinguinha e com Baden Powel exprime esse encontro entre o samba, a cultura afrobrasileira e a classe média. É nesse mesmo contexto que o jornalista Sérgio Porto, o Stanislaw Ponte Preta, se aproxima de Agenor do Nascimento, o Cartola, enquanto lavador de carros. O bairro da Tijuca e toda a cercania que o envolve, de Vila Isabel ao Estácio, já vinha experimentando uma rica relação desde Noel Rosa chegando até Aldir Blanc, Gonzaguinha, Ivan Lins, Jorge Ben Jor, Luiz Melodia. Relação essa que não deixou de ter suas rudezas na tensão entre o samba e os valores de uma classe média ascendente e um gênero próprio de samba que viria a ser chamado de "samba bandido" (Viana, 2001) do qual Wilson Batista é um pioneiro.

Wilson Batista intelectual orgânico (Gramsci) com sua leitura de mundo a partir desses espaços de conformação da subjetividade dos grupos subalternizados das favelas nos oferece uma leitura a partir de um mundo que em parte se reconhece nele. Mais que conhecido é reconhecido pelos grupos sociais com que contribui para forjar sua identidade (Pierre Bourdieu). O samba "Lenço no Pescoço", de Wilson Batista, foi interpretado por Noel Rosa como ode à malandragem em seu "Rapaz Folgado", o que valeu uma seqüência ríspida de desafios que foi de "Mocinho da Vila", de Wilson Batista, ao "Feitiço da Vila" de Noel Rosa, à "Conversa Fiada" de Wilson Batista, além de outras letras que culminaram, mais tarde, na aproximação dos dois gigantes da música popular brasileira.

Wilson Batista, em parceria com Roberto Martins, nos brindaria, em 1950, com uma música de protesto, uma das primeiras de que se tem notícia, com seu Pedreiro Waldemar onde nos deixa uma boa pista para 
entendermos a complexa leitura popular das contradições sociais inscritas na nossa cidade. "Você conhece o pedreiro Waldemar?/ Não conhece? Mas eu vou lhe apresentar/ De madrugada toma o trem da Circular/ Faz tanta casa e não tem casa pra morar/ Leva marmita embrulhada no jornal/ Se tem almoço, nem sempre tem jantar/ O Waldemar que é mestre no oficio/ Constroi um edificio/ E depois não pode entrar/ Voce conhece o pedreiro Waldemar?/ Não conhece, mas eu vou lhe apresentar/ De madrugada toma o trem da Circular/ Faz tanta casa e não tem casa pra morar”.

Esse gênero de poesia/samba terá seguimento na obra de Bezerra da Silva e de vários rappers, como MV Bill ${ }^{13} 15$, da Cidade de Deus, ou Mano Brown do Capão Redondo em São Paulo que, inclusive, vão se ver frecuentemente acusados de fazerem apologia do tráfico e da violência quando, na verdade, trazem uma leitura de mundo própria onde os subalternizados não veem perspectivas de afirmação através dos canais que a ideologia dominante oferece. De seu ponto de vista, como através do trabalho podem ter acesso ao mundo do "baú da felicidade" midiaticamente oferecido todos os dias todo o dia? Eis a contraface de um mundo onde cada um se afirma pelo que tem e não necessariamente pelos caminhos que lançou mão para ter.

Bezerra da Silva, como todo bom intelectual orgânico, reivindica seu lugar próprio de leitura de mundo: "Meu bom doutor/o morro é pobre e a pobreza/não é vista com franqueza/nos olhos desse pessoal/ intelectual” ao afirmar seu juízo sobre o mundo e desqualificando o julgamento dos "de fora”: “Ah! Meu bom juiz, meu bom juiz/não bata esse martelo e nem dê a sentença/antes de ouvir o que o meu samba diz/pois esse homem não é tão ruim como o Senhor pensa”. A ambigüidade discursiva própria ao que se chamou mundo da malandragem deve ser vista na tessitura desse mundo de elevada complexidade onde o que lhes é oferecido pela sociedade envolvente é tão pouco "mas quando alguém se inclina com vontade/ em prol da Comunidade/jamais será marginal/buscando um jeito de ajudar o pobre/ quem quiser cobrar, que cobre/pra mim isso é muito legal”, ainda Bezerra da Silva.

Estamos longe de uma dialética empobrecida entre um dentro e um fora, entre grupos subalternizados e grupos sociais burgueses e de classe média, ainda que tais posições sociogeográficas façam parte das complexas interações que aqui se fazem presentes. No interior desses espaços, dessas comunidades, múltiplas leituras se fazem e múltiplas relações se estabelecem tanto no interior como fora e nas suas interações. Basta observarmos a diferença entre MV Bill e sua CUFA, de um lado, e Mano Brown e os Racionais MC's, de outro.

MV Bill passou a ter uma relação intensa com o mundo da mídia participando de programas assistenciais como Criança Esperança promovido pela UNICEF e Rede Globo de Televisão, além de ter o patrocínio de uma das empresas gigantes do mundo da telefonia, a Nextel. MV Bill promove uma série de atividades educativas junto a várias comunidades de 
favelas no Rio de Janeiro. Já o grupo “Racionais MC’s opta para uma relação de ruptura com a mídia formal, recusando convites para participação nos veículos de comunicação mais influentes do país, abrindo uma exceção, apenas para o programa Roda Viva ${ }^{14}$. Os Racionais MC's criam “empresas paralelas" de produção musical onde atendem rappers detidos e em regime de reclusão, conseguindo, inclusive, alvará especial para que eles possam fazer shows fora dos presídios. Os Racionais Mc's desenvolvem, ainda, irmandades, é assim que se auto-denominam em uma das suas canções, onde atendem crianças das periferias, principalmente do Capão Redondo, área de extrema pobreza e marcada pela violência urbana.

Essas filiações históricas dos artistas da favela permitem perceber como historicamente tais tensões estiveram presentes nas interações entre aqueles que se constituem a partir da experiência com as favelas e o fascínio que isso provoca nas redes sociais e econômicas fora das favelas.

A perspectiva de quem está numa posição subalterna numa sociedade de herança escravocrata marcada pelo patrimonialismo e que vê o trabalho como coisa de pobre, quando não coisa de negro, proporciona a idéia de que a liberdade vem pela sorte e não pelo trabalho. "Acertei no milhar/ ganhei 500 contos/ Não vou mais trabalhar" diz o mesmo Wilson Batista tal como no samba "Lenço no Pescoço" que tanta celeuma causou. "Meu chapéu do lado/ Tamanco arrastando/ Lenço no pescoço/ Navalha no bolso/ Eu passo gingando/ Provoco e desafio/ Eu tenho orgulho/ Em ser tão vadio/ Sei que eles falam/ Deste meu proceder/ Eu vejo quem trabalha/ Andar no miserê/ Eu sou vadio/ Porque tive inclinação/ Eu me lembro, era criança/ Tirava samba-canção/ Comigo não/ Eu quero ver quem tem razão/ E eles tocam/ E você canta/ E eu não dou”.

Considere-se ainda que seja pelo trabalho, ainda que precário, seja pela relação com/contra o tráfico, seja pela sorte, seja se relacionando com o mundo midiático-empresarial, seja através de ONGs, resta ainda a salvação pela irmandade, seja ela pela via da auto-organização de empresas paralelas, seja com os criminalizados já julgados, seja com os criminalizados pelo senso comum forjado pela ideologia dominante, podese tentar sair pela via do "ópio do povo" procurando um consolo ideal para um mundo que concretamente não tem consolo (Marx) que bem pode ser uma religião. Sendo assim, a partir de um mesmo mundo múltiplas visões de mundo. Enfim, há uma crítica social em todas essas práticas, ou essas práticas indicam, todas, uma situação social crítica, é o que nos permite um olhar para esse mundo com uma perspectiva teórico-política que os ouça, que os sinta e não com a visão criminalizadora com que se os aborda.

\section{A viragem da lógica do favor para a lógica do pavor}

Os anos 1960 assistirão ao início do ocaso desses encontros e a exacerbação das contradições que vão conformando novos padrões de sociabilidade na cidade do Rio de Janeiro. É o momento que Chico Buarque 
vê o fim do tradicional "malandro carioca" que ele vê se tornando trabalhador, em que o malandro se torna um "malandro federal”. Mas Chico Buarque viu logo adiante "Meu Guri” já anunciando a lógica do pavor se sobrepondo, e não substituindo, à lógica do favor. A década de 1960 foi a da viragem sócio-geográfica da sociedade brasileira. 1960 é o ano do último censo em que a população rural brasileira é maior que a urbana. Enfim, em algum ano entre 1960 e 1970, o Brasil passou a se tornar principalmente urbano e essa urbanização se deu, desde 1964, sem liberdade de expressão. Socialização sem direitos.

Consideremos que sendo essa população, até então, sobretudo rural e se urbanizando rapidamente, estávamos diante de uma população sem escolaridade formal e, por isso mesmo, com forte expressão cultural áudio e visual do que o cancioneiro popular e a cantoria que acompanha o cordel $^{15}$ são belos exemplos. E, nesse exato momento, a ditadura e sua modernização conservadora unifica o país com a Embratel e as redes de televisão em cadeia (sic) nacional. A Rede Globo de Televisão, por exemplo, é criada em 1965. Aqui reside a dívida da televisão brasileira para com as nossas melhores e mais profundas tradições culturais.

Ali, naqueles anos sessenta, o Brasil que se afirmou com a ditadura foi o Brasil que não quis fazer a reforma agrária, que não quis fazer a reforma urbana e não quis aprovar a lei que limitava as remessas de lucro para o exterior, e aqui me restrinjo a ficar nos termos explicitados na agenda política de época que foi golpeada mergulhando o país nos anos de chumbo. Toda essa mesma agenda política é atual num sentido muito preciso, qual seja, coisa de outro tempo que continua atuando e explodindo como conflito social na sua forma anti-política, como diria Hanna Arendt, enquanto violência.

\section{As especificidades políticas da formação territorial do Rio de Janeiro}

O processo de territorialização que se forja na cidade do Rio de Janeiro remete a uma história ligada ao fato de a cidade ter sido, até os anos 1960, capital da república e, depois, ter se visto diante de uma nova conformação política imposta por uma ditadura (1964-1985) em que se produziu uma fusão de poderes oligárquicos do antigo estado do Rio de Janeiro com um estado sem tradição política própria, como o estado da Guanabara.

Dificilmente um político, mesmo uma figura do porte político do Sr. Leonel Brizola, se aventuraria a se candidatar a governador de estado fora de seu estado natal, como o Sr. L. Brizola fez, em 1982, no Rio de Janeiro, em parte por essa razão sucintamente acima invocada.

Afinal, a ex-capital federal, exatamente por sua politização, se vira expropriada dessa condição política com a transferência da capital para 
Brasília, como bem o demonstra o excelente livro A Capital da Geopolítica de José William Vesentini (Vesentini, 1996). Mas a memória dessa violência política que subjaz à transferência da capital, com todo um séquito de efeitos no que chegou até a se constituir numa síndrome do novo estado como a “decadência do Rio de Janeiro”, vai encontrar guarida na crise da ditadura e no imaginário popular.

Talvez uma cena que um dos autores desse artigo presenciou no exato momento em que se noticiava que a sigla do PTB - Partido Trabalhista Brasileiro - ficava sob controle de setores de direita, como a Sr ${ }^{\mathrm{a}}$ Ivete Vargas, pode ser esclarecedora do que estamos invocando. Vamos ao fato: em frente ao Hotel Serrador, na Rua Senador Dantas, uma rua localizada numa quadra atrás da Cinelândia, bairro do centro da cidade do Rio de Janeiro, jornalistas se acotovelavam para buscar a opinião do Sr. Leonel Brizola, recém-chegado do exílio e o grande perdedor no julgamento do STF que lhe retirava a sigla do partido de que era, sem dúvida, a maior expressão nacional. Entre solicitações de "Brizola, por favor!”, "Brizola, o que acha da decisão do Supremo?”, observei pequenos jovens, meninos de rua, engraxates, saindo correndo pelas estreitas ruas que ligam a Senador Dantas à Cinelândia, gritando "liberaram a Brizola!, “liberaram a Brizola!”. De imediato, não foi possível ligar os sentidos distintos de Brizola que dali emanavam. Pouco tempo depois, na eleição ${ }^{16}$ de 1982, o slogan da campanha de Leonel Brizola mostraria toda a criatividade do marketing político e sua fina capacidade de captar o imaginário popular e que viria ligar aqueles sentidos distintos de Brizola que ouvira na porta do Hotel Serrador cerca de um ano antes.

“Brizola na cabeça!”, eis o slogan mágico. São múltiplos os sentidos aquí possíveis: "Brizola” é o nome como a cocaína ficou conhecida no imaginário popular depois do golpe de 1964 que, assim, a associava aos políticos que foram proibidos; “na cabeça” é uma expressão popular que está ligada a uma modalidade de aposta no chamado “Jogo do bicho” e que significa acertar no prêmio principal. "Na cabeça” ganhara um sentido próprio nessa primeira eleição a governador desde 1964 porque a ditadura criara uma regra em que o eleitor estava obrigado a votar no candidato do mesmo partido desde a cabeça, no caso para governador, até as eleições proporcionais a deputados. Assim, "Brizola na cabeça” era um chamamento a fortalecer o candidato Leonel Brizola. Ao mesmo tempo "Brizola na cabeça” é também não só o “jogo do bicho”, mas também “fazer a cabeça”, expressão que, do mundo da umbanda, se espraia pela cultura popular e significa "usar droga" que, tal como o candidato que se pede que se vote à cabeça, era, até ali, também proibido. Enfim, o "liberaram a Brizola” era também liberar o proibido e, sem dúvida, esse slogan se inscreve como uma das maiores criações do marketing político de todos os tempos. Mas, atenção: por mais que estejamos diante de uma estratégia político-eleitoral bem-sucedida e por mais inteligente que seja esse slogan temos que vê-lo muito mais como resultante de múltiplas circunstâncias do que simplesmente como uma estratégia unidirecional. Todavia, podemos ver aqui uma tradição de pensamento de fortes raízes na formação social brasileira (e latino-ame- 
ricana) de lideranças políticas com profundas relações com a cultura popular, mesmo sendo, muitas vezes, lideranças políticas oligárquicas e conservadoras. É o lado nacionalpopular- conservador que tem na ideologia da democracia racial, na mestiçagem e no homem cordial três suportes político-culturais fortes.

A mestiçagem, mais que uma constatação de um fenômeno sociológico de mistura de raças, seja lá o que isso signifique, é quase um imperativo categórico de um destino inexorável que impede que se seja negro, que se seja índio, como se essas afirmações identitárias negassem a democracia racial. Ou seja, na democracia racial não se pode ser negro ou ser índio, pois estamos todos condenados a ser mestiços quando, então, as diferenças se diluem. No máximo mulatos que, como as mulas, não se reproduzem. Autoritarismo cordial.

O conceito de "homem cordial” de Sérgio Buarque de Holanda nos dá boas pistas analíticas por suas implicações contraditórias e que nos ajuda a compreender a nossa subjetividade socialmente violenta. Afinal, tanto quanto a docilidade que o termo cordial invoca, ele trás também o radical cordis, coração do latim, e, assim, cordial é aquele que se deixa levar pela emoção do momento e, deste modo, pode ser também extremamente violento, conforme a sugestiva interpretação de Marcos Alvito, em mesa redonda na Universidade Federal Fluminense onde partilhou essas reflexões junto com o rapper MV Bill.

Todavia, não é só no mundo da política explícita que pudemos surpreender essas mediações das relações de poder que mergulham nas profundas relações do imaginário popular, como vimos no caso do "Brizola na cabeça”.

Como disse o poeta Nelson Sargento: "Samba, agoniza/ mas não morre/ alguém sempre te socorre/ antes do suspiro derradeiro/ Samba, negro forte e destemido/ foi duramente perseguido/ na esquina, no botequim, no terreiro/ Samba negro forte, pé no chão/a fidalguia do salão/ te abraçou, te envolveu/ mudaram toda tua estrutura/ te impuseram outra cultura/ e você nem percebeu”. A escola de samba já havia sido enquadrada pelo Estado Novo onde o nacionalismo-popular-conservador o fez saudar os heróis da "nossa história” sob a chancela do Ministério da Cultura. História oficial feita pelo povo!

Com o início da indústria cultural e seus suportes midiáticos empresariais e diante das transformações profundas da sociedade brasileira e carioca, desde os anos 1960, os contraventores que sempre estiveram, em maior ou menor grau, à frente das escolas de samba se viram tendo que se modernizar. Percebendo que haveriam de se adequar às novas realidades esses contraventores resolvem convidar artistas, sobretudo de televisão, para serem destaques nos desfiles de escolas de samba. Assim, artistas de TV subirão nos carros alegóricos lado a lado com as mulheres dos contraventores exibindo seus corpos belos dando ensejo a que pouco a pouco se 
chamará “o maior espetáculo da terra”, onde o bloco de poder midiáticoturístico se alia à contravenção e vai aos ares, em cores. 10, nota 10 !, assim brada o locutor da LIESA - Liga Independente das Escolas de Samba do Rio de Janeiro - para anunciar as notas das escolas de samba nos desfiles de carnaval. Até onde conseguimos registrar é o único caso em que o mestre de cerimônia não é um artista da principal rede de televisão, mas sim o locutor oficial da liga das escolas de samba cujo poder é claro!

E mesmo nesse terreno denso, de relações plásticas, flexíveis, informais, de extrema valorização das relações personalizadas, onde a palavra vale mais que a lei, enfim nesse mundo da para-legalidade, como no caso do "jogo do bicho", ainda "vale o que está escrito”. Mas ali não se trata de uma escrita impessoal, pois todos sabem "quem” garante o que está escrito, não só porque esse "quem” perde a credibilidade se não pagar o que está escrito, mas também porque todos sabem que esse "quem" tem o poder “de fato", inclusive no controle do "ponto", da “rede de pontos”, do territóriorede, (Hasbaert, 2004). Lógica do pavor, ainda que garantindo o prêmio!

Eis algumas das múltiplas determinações que subjazem à formação territorial do Rio de Janeiro, reconfigurada pela intensidade e pela magnitude do processo expropriatório de camponeses e camponesas que se abateu sobre a sociedade brasileira (e latino-americana) nesses últimos 30/40 anos, com dimensões jamais vistas em qualquer país e em qualquer época, e diante de um conjunto de políticas em que o estado se (des)nacionaliza e se (des)democratiza, conforme as ricas expressões de Aníbal Quijano para indicar que o estado abandonou a nação e abdicou de ser o guardião dos direitos da população e, assim, da cidadania e da democracia. A isso chamase neoliberalismo.

Nesse complexo de relações sociais, culturais e políticas geográficamente configuradas, um poder de fato se faz presente nessas comunidades de periferias urbanas, agora instado pelas oportunidades de negócios abertas pelo mercado das drogas e pelo mercado das armas ampliado com o processo de globalização que, assim, se mostra localmente perverso, sobretudo para a maior parte dessas populações pobres controladas pelo poder de fato e que envolve as instituições policiais e o crime de modo sistêmico ${ }^{17}$.

Enfim, há uma história incorporada e uma história objetivada, um habitus nesses habitat e nesses habitantes, como diria Pierre Bourdieu, onde o poder de facto, não de jure e muito menos consentido a não ser no que isso é possível nas circunstâncias de um poder de facto, comanda as práticas sociais e de poder. Lógica do favor se transformando em lógica do pavor cada vez mais e, sobretudo para as populações locais e, de quando em vez, para a cidade como um todo quando uma bala perdida, então, vê a violência ser noticiada. Como nos disse um jovem intelectual que a partir da própria experiência elaborou a seguinte reflexão: "para nós, "bala perdida” é quando não encontra um corpo de um pobre negro, quase sempre jovem, pois se o atingiu parece ter atingido seu destino" (Jonathan Marcelino) ${ }^{18}$. 
A magnitude do mercado de drogas e do mercado de armas atingiu proporções imensas com a desregulamentação financeira, inclusive com seus paraísos fiscais. A burguesia que opera esses mercados não está simplesmente interessada no valor de uso socialmente sancionado, mas no símbolo dos símbolos dessa sociedade do espetáculo (Guy Debord) e de seus simulacros (Baudrillard): o dinheiro, a acumulação do capital (Marx). Por isso, estamos diante de um poder paralelo e não de um poder simplesmente ilegal, voltaremos a esse tema mais adiante. O que se visa é um dinheiro limpo, legal, que, exatamente por isso, se encontra com atividades perfeitamente legais, como lojas de revenda de veículos, comércio de importação e exportação, comércio de jóias e pedras preciosas, financiamento de garimpos, promoção de eventos, essas atividades são particularmente promissoras para o negócio, pois sendo eventuais são de rotinas menos estabelecidas e, portanto de difícil fiscalização, além de envolverem mercadorias de preços extremamente subjetivos como os cachês de artistas e de suas entourages. Os bancos são o destino final de todas essas operações: não se é traficante para poder cheirar ou fumar maconha ou marijuana ou crack ou ecstasy, mas para ganhar dinheiro. E tudo isso conecta os bastidores de Wall Street e da City de Londres, Paris, Frankfurt, Tókio, Pequin, São Paulo ao Afeganistão e ao ópio da papoula e à coca dos confins dos Andes desde o Chapare, na Bolívia, às matas peruanas e colombianas, ao Espiñazo del Diablo ${ }^{19}$ no sul do México, em Chiapas, alimentado pelos paraísos das Bahamas, Ilhas Jersey, Ilhas Cayman e tantos outros.

O Brasil, que na rota do mercado da droga não se inscreve como grande produtor, mas sim como um consumidor médio, mas em ascensão como economia emergente, oferece mão de obra barata e uma oportunidade de negócios expedita no encontro de uma polícia com fortes tradições de convivência com a para-legalidade. A mais visível e historicamente folclorizada é a relação complacente com o jogo do bicho. "O Chefe da policia pelo telefone mandou avisar/ que na Carioca tem uma roleta para se jogar”, como já dizia a letra do primeiro samba com autoria registrada por Donga e Mauro de Almeida. Já ali, polícia e bandido sambando juntos. Gilberto Gil, que mais tarde seria Ministro da República, revisitou a Idoia em seu Pela Internet dizendo "que o chefe da polícia carioca avisa pelo celular/Que lá na Praça Onze tem um videopoquer para se jogar” adaptando a letra do samba de Donga e de Almeida aos tempos informático-digitais. Ainda hoje dançamos ${ }^{20}$, agora via satélite e pela internet.

Essa tradição se vê agora pressionada por mega-eventos, como a Copa do Mundo de 2014 e as Olimpíadas de 2016, onde um mercado de grandes investimentos é desatado, tanto o mercado imobiliário, como o mercado da segurança, como o turístico, com tudo que este mercado, em particular, costuma trazer junto, além de turistas - drogas, prostituição, jogos - e que põe em xeque um tipo de criminalidade violenta que tende a afugentar tudo isso.

Não deixam de ser visíveis as novas formas de criminalidade que vêm se impondo nas periferias, isto é, nos bairros pobres do Rio de Janeiro 
e do Grande Rio, com o para-militarismo das milícias em que policiais militares e civis impõem às populações a lógica do pavor com mercados clandestinos de transportes (motos), de distribuição de água, gás e de redes de transmissão de TV a cabo, a GatoNet, inclusive com pagamento feitos com boletos bancários. Estamos longe de atividades ilegais, mas exatamente de atividades para-legais, até porque os parcos salários pagos aos policiais, assim como a flexibilização no cumprimento da lei lhes faculta prestar/ vender serviços privados, e abertamente os convida a fazer um serviço paralelo onde se faz vista grossa ao direito de vida e de morte que esses mesmos policiais passam a dispor. Vender segurança é sua expertise e, assim, a segurança pública é submetida à lógica dos interesses de quem pode pagar e dos que vendem, enfim, lógica do pavor institucionalizada. Sofrem os que estão fora desse mercado, ou seja, a maioria que, sobretudo é pobre. Entre os que podem pagar se inclui o próprio narco-empresário que também compra armas e tem o abastecimento garantido. Nas favelas, fala-se abertamente do aluguel de "caveirões" para transportar armas até os lugares seguros e, assim, garantir o controle do território por distintas facções.

E assim, hoje, se reconfiguram as tradições de um estado patrimonialista que sempre se caracterizou pelo que agora se considera novo, a parceria público-privado que, entre nós, sempre se caracterizou pela instrumentalização do poder (que deveria ser) público pelos interesses privados. Tudo indica que estamos diante de uma reconfiguração da geopolítica do crime no Rio de Janeiro, com as UPPs ${ }^{21}$ - Unidades de Polícia Pacificadora. Consta que a venda de drogas sem armas ostensivas estaria sendo tolerada nessas áreas ocupadas pelas UPPs inaugurando uma forma light de venda de entorpecentes mais compatíveis com os grandes eventos de que o Rio vai ser palco.

O comportamento dos políticos na última eleição, em particular no estado do Rio de Janeiro, parece corroborar a tese que invocamos. Como destacou o antropólogo Luiz Eduardo Soares em entrevista ao Programa Roda Viva da TV Cultura de 29/11/2010, pela primeira vez não observamos políticos sendo fotografados com chefes de milícias que até muito recentemente lhes garantiam currais eleitorais.

Tudo indica que a CPI das milícias, que sob a liderança política do Dep. Marcelo Freixo, conseguiu colocar atrás das grades um Secretário de Segurança Pública e parlamentares ligados às milícias, talvez tenha contribuído para evitar que se precipitasse entre nós o que se poderia caracterizar como o início da mexicanização/colombianização do crime. Mas a julgar pelos resultados das eleições e pelo comportamento da mídia, a tendência não está definida. É o que diz um pouco do resultado das eleições e sua geografia, pois assim como o Dep. Marcelo Freixo foi o segundo mais votado para deputado estadual, o primeiro mais votado foi um candidato da mídia que defende a tese do "bandido bom é bandido morto", o Sr. Wagner Montes.

De interessante registre-se o fato de aproximadamente $10 \%$ dos 177 
mil votos de Marcelo Freixo ter sido registrada em área de milícias, onde o candidato sequer conseguiu entrar para fazer campanha. Enquanto isso, o comando militar-midiático da mega-operação contra o Complexo do Alemão continua brandindo que se trata da ocupação dos "de bem" contra os "do mal” num binarismo que ignora que não temos dois lados, mas um complexo sistêmico policial que é o cerne de todo o problema, conforme insiste o antropólogo Luiz Eduardo Soares, e que conta ainda com o beneplácito da mídia. A expressão "bandido bom é bandido morto" consagrada por um policial-jornalista é emblemática. Afinal, bandido vivo fala e, se fala, pode depor e, se depõe, fatalmente põe em risco o policial implicado com o crime. Mate-se-o. Eis o xeque-mate em que nos encontramos.

O setor de segurança pública se manteve blindado, para usar uma expressão que lhe é cara, no processo de redemocratização da sociedade brasileira, setor-limite da "transição transada". Eis a caixa-preta que deve ser aberta para que possamos realizar a utopia sentida no ar durante os dias da operação no Complexo do Alemão que é possível que o poder público, inclusive as forças policiais, possa estar ao lado do povo e não contra, e que se pode entrar numa favela sem que seja atirando, talvez o melhor saldo da mega-operação contra a lógica do pavor no Complexo do Alemão. Sem controle social e democrático do poder instituído ele deixa de ser poder verdadeiramente público. Poder público ou é democrático ou não tem legitimidade!

\section{A complexa territorialidade das favelas: os moto-taxistas, um moto próprio}

Na favela ninguém vai para o exército de reserva.

Todos são da ativa.

Uma notícia veiculada pelo comando militar-midiático da megaoperação de invasão do Complexo do Alemão e Vila Cruzeiro nos informa que a polícia havia encontrado mais de 320 motos um dia após ter o controle de todo o Complexo. Segundo a fonte todas as motos eram roubadas.

A lógica da criminalização e a cultura do medo que informam a notícia acabam por deixar escapar a compreensão do que está implicado nas territorialidades das favelas. Essas motos são uma boa carona para a compreensão dessas territorialidades. Na favela da Rocinha, por exemplo, fala-se da existência de mais de 2000 dessas motos. Quem percorre a América Latina, de São Paulo a Trinidad no interior do Beni na Bolívia, de Caracas até a cidade de Coro e Colima na Venezuela, ou pela cidade do México passando por Juchitan ou Matias Romero (Oaxaca), haverá de ver o número de motos usadas, sobretudo pela população pobre ${ }^{22}$.

A existência desses objetos dá conta das profundas relações do mundo dessas comunidades com o seu entorno urbano e com o mundo da indústria. 
Milton Santos fez um enorme esforço para chamar a atenção para a racionalidade dessa economia relacionada à pobreza urbana, para sua complexidade. Denunciou explicitamente o preconceito e o etnocentrismo com que se aborda a realidade dessas populações, os limites de teorias como as da marginalidade e mesmo aquelas que fazem exegese dos textos de Marx e não mergulham na realidade empírica dessas populações. Chegou a falar dos dois circuitos - o superior e o inferior - que caracterizava a cidade, sempre interligados entre si por relações de dominação assim como à formação social de cada estado territorial e ao sistema mundo capitalista e colonial, como bem sabemos hoje. Milton Santos foi um dos pioneiros na formulação de uma teoria crítica da economia política do espaço com enorme sensibilidade social e, sobretodo preocupado em entender a lógica criativa de reprodução dos pobres como parte de um modo de produção que reproduz desigualdades (Santos, 1965; 1971; 1975; 1979; 1979a; 1980; 1982 e 2004 [1978]).

Já indicamos as condições dos sítios onde se localizam a maior parte dessas comunidades, quase sempre em terrenos irregulares, sejam íngremes, sejam alagados, com frequiência sobre antigos lixões, como vimos recentemente no Morro do Bumba em Niterói ou no Bairro do Coque em Recife. Lugares desvalorizados e, por isso, ocupados por gente que a sociedade atribui a mesma valorização.

São áreas de difícil ocupação onde as vias de acesso são construídas na estreita necessidade do que sobra da construção do abrigo da casa que, sendo muitos, são vias estreitas adequadas à topografia e às necesidades do número. Nesses espaços freqüentam o "pedreiro Waldemar" e homens de "lenço no pescoço", personagens de Wilson Batista.

Aquelas motos que o noticiário destacou o lado criminal se inscrevem nessa territorialidade complexa em que os transportes públicos não só inexistem como tais, aliás, como quase tudo que deveria ser de caráter público, como sequer podem circular por essa geografia caracterizada por becos e vielas sinuosos como a vida de cada um dos seus habitantes. As motos superam a rugosidade física do terreno, a rugosidade social dos casebres solidários e a rugosidade do poder das "contenções" de trilhos de trem fixados e muros ou buracos intencionais de defesa do território sob o comando do poder de fato. O concreto solidário dos casebres onde a laje é o piso que aumenta com o aumento da família é o mesmo concreto que solidariamente despenca numa chuva mais intensa quando perdem toda solidez. Tudo que é sólido pode desmanchar na próxima chuva, é a versão favela do Manifesto. A insegurança é mais complexa quando vista de dentro da favela.

As motos têm a flexibilidade adequada a esses espaços e permitem uma circulação até muito recentemente impossível. 

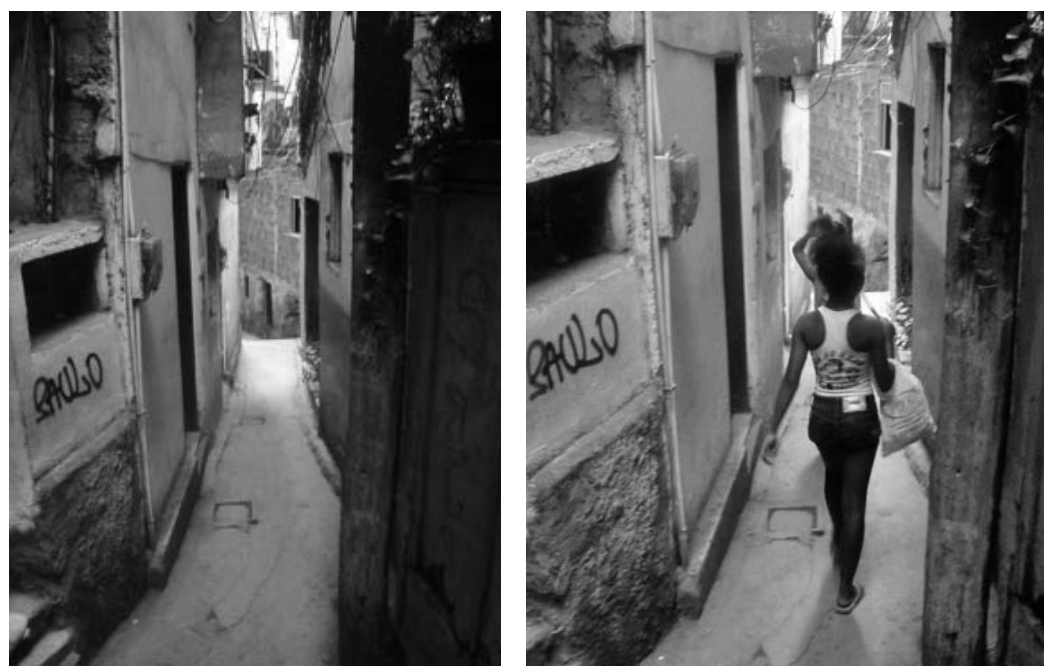

È freqüente se ver montado numa moto até mesmo três pessoas de uma mesma família, o que seria multado no espaço urbano fora da favela. As compras podem ser entregues delivery, assim como o gás e a água, dando um conforto e empregos que a notícia da moto roubada sequer imagina. E veja que na Rocinha se conta em 2000 o número de motos, repetimos.
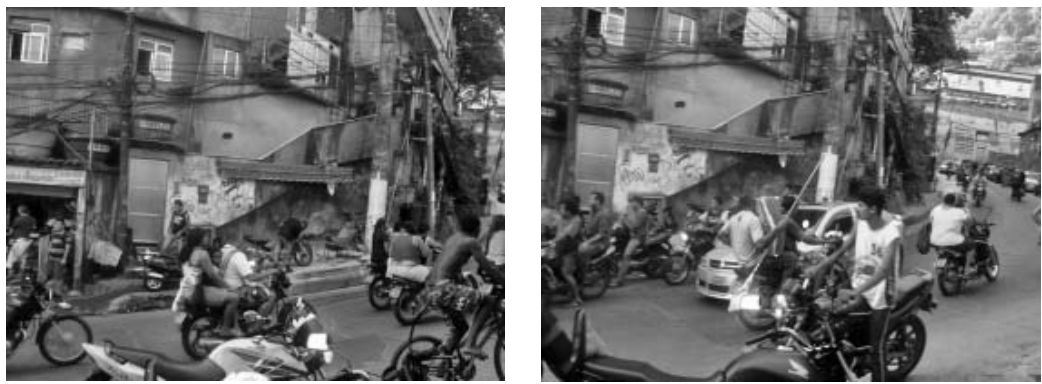

Em cima de uma moto há um jovem empregado com o mesmo sonho dos jovens que hoje sonham com aquela casa com piscina, iluminação indireta, piso imitando Copacabana e TV de plasma que, provavelmente na véspera de ser notícia na invasão do Complexo do Alemão, transmitia o noticiário de cujos intervalos os telespectadores alimentavam seus sonhos. Muito provavelmente esse jovem não tem a carteira de habilitação, mas a lógica da favela o emprega, ela é flexível como as motos tendem de ser para vencer as rugosidades daquele espaço de vida, de risco.

Muitas vezes esse moto-taxista desenvolveu sua expertise para dirigir motos no interior do nordeste e, na falta de perspectiva de uma reforma 
agrária que o contemple e lhe ofereça perspectiva de uma vida digna no lugar de origem, encontra na favela uma colocação que lhes é indicada pelos parentes que sabem dessas oportunidades. [Ter algum tino comercial é outra expertise muito valorizada, pois sempre há uma birosca abrindo oportunidades de negócios].

Tal como lá no interior o moto-taxista sabe que tem que ser “sujeitohomem” (Alvito, 2001: 252) e se diz que sabe dirigir tem que arcar com as conseqüências, caso ocorra um acidente. É a lógica da favela, “papo reto” (Torquato da Silva).

Há uma lógica ambígua que atravessa toda a territorialidade da favela, é seu moto-próprio. Não é uma lógica estranha para aqueles que sabem posto que a experimentaram ainda muito recentemente, quando não ontem, sob a lógica autoritária do coronel latifundiário que, por favor, o empregava na fazenda em troca de comida e de abrigo. Seu corpo muitas vezes traz essa curvatura e seu linguajar quase sempre diz “obrigado” e sabe muito bem quem tem o poder de mando, pois conhece seus jagunços. Enfim, sabe com o corpo assim como se sabe com o tato ${ }^{23}$. Não se pense que estamos falando de um Brasil anacrônico ou em vias de extinção ${ }^{24}$. No mesmo instante que o noticiário da mega-operação militar-midiática no Complexo do Alemão vem a notícia de que 60 pessoas foram libertadas da condição análoga a de trabalho escravo no município de Mauá, a 20 quilômetros da cidade de São Paulo. Eram todas nordestinas. É esse habitus, essa história objetivada e essa história incorporada que nos dá os currais eleitorais tanto lá no interior como aqui. Há mais continuidades nessas discontinuidades sócio-espaciais do que admitimos. É essa violência inscrita na lógica do favor que é o cavalo ${ }^{25}$ da lógica do pavor. A moto, roubada ou não, não está ali para transportar droga, exclusivamente, ainda que o faça em certas circunstâncias. Ela se inscreve num conjunto de relações sociais que viabiliza a reprodução creativa daquelas populações nas circunstâncias possíveis. As relações de trabalho envolvem jovens em situações distintas com o mundo do tráfico, desde o envolvimento completo até o parcial. Não há lugar para todos no mercado do tráfico, embora a “empresa”, facção ou milícia, cobre a diária de cada moto-taxista e controle a distribuição de gás e de água. Aquele que não tem escolaridade, boa aparência ou já passou da idade encontra de um modo ou de outro emprego nessa rede de relações de parentesco e vizinhança posto que é filho de "Dona ...” ou sobrinho de "Dona ..." ou de "Seu" que é compadre do ... É esse conhecimento do espaço por meio das relações comunitárias fortemente personalizadas que permite que se chegue a todo lugar mesmo sem endereço formal. Tudo isso cria cumplicidades e está "sob controle” e vigilância. Há uma ambigüidade atravessando essas complexas relações onde o legal e ilegal conformam a para-legalidade dessas territorialidades onde a acumulação primitiva alimenta, e se alimenta, de mais valia o capitalismo globalizado. A lógica de mercado de trabalho na favela prioriza não somente a idade ou a força de trabalho produtiva, mas comporta numa economia moral onde o morador da "comunidade" deve encontrar uma "viração", enfim, não debe ficar "no sufoco”. Assim, para uma pessoa com mais de 50 anos de idade 
desempregada no emprego formal, não é o seu fim na lógica da favela. Mesmo que não tenha dinheiro para investir numa moto, ou mesmo na carteira de habilitação, basta ter aprendido com a prática e saber conduzir minimamente uma moto que ele será incorporado ao mercado de trabalho interno-local. E seja sujeito-homem, papo-reto.

Hoje, nas favelas do Rio de Janeiro, e quem sabe em outras cidades, há regras criadas no interior dessas comunidades que configuram uma territorialidade sui generis onde a "profissão" de moto-taxista joga um papel importante. Esse tipo de trabalho e prestação de serviços incorpora trabalhadores descartados pelos empregos formais. Cria, também, critérios de contratação diferenciada, porém, adequada às circunstâncias.

O mesmo regime de trabalho que o emprega, é também o regime de justiça que o condena, conforme veremos a seguir. Geralmente é o tráfico que comanda as regulamentações do funcionamento espacial que possibilita o trânsito e o tráfego local. Caso aconteça um acidente, o condutor do veículo será julgado dentro do entendimento situacional e da interpretação de testemunhas oculares que, assim, assumem a co-responsabilidade com o tráfico da pena decretada para o bem comum. Há níveis de legitimidade no interior do poder de fato, afinal, morte por acidente no trânsito não é tolerada pela comunidade. Como se trata de um setor sob absoluto controle do poder de fato ele se legitima ao garantir esse interesse geral.

Quando o morador, em situação de desemprego, descartado pelas formalidades empregatícias porque não tem carteira de habilitação, currículo profissional, ou experiência comprovada encontra-se numa situação limite, ele sabe que na favela, ainda não é o fim, há escolhas que impedem a humilhação plena da falta de dinheiro: a mendicância. Ele pode recorrer a uma lógica societária que o percebe para além das exigencias formais ou vive dessas ausências para criar suas oportunidades de negócios.

Ao pedir uma autorização ao tráfico para trabalhar no moto-taxi, ou até mesmo para montar uma barraca de camelô em um ponto da favela, o morador não está necessariamente se filiando ao tráfico, mas aderindo a uma força de comando e de regulações do território que o integra como trabalhador. E, mais que isso, o coloca em um circuito dinâmico de relações que o mantém vivo socialmente. Não há consentimento. Há circunstâncias. E a polícia, cada um bem o sabe, “chega junto”, “facilita o negócio”, portanto, é aceitar ou aceitar ${ }^{26}$.

Como diz um morador da favela da Rocinha: "Um senhor de 50 anos que entra para um ponto de moto-táxi passa a viver relações de extrema excitação. Lida com os jovens moto-taxistas que além de trabalhar, namoram muito. Ter moto, não só na favela, atrai muitos amores. Lida também com a locomoção de alguns bandidos que queiram se deslocar dentro da favela. Afinal, como ele não sofreu preconceito para ser incorporado no mercado interno de trabalho, seria uma incoerência demonstrar preconceito com as lógicas existenciais da favela". Como se vê a 
flexibilidade dos sem-direitos é complexa. A favela não admite rigidez. “Tá ligado?!”. Sambar no pé e requebrar as cadeiras é natural desse espaço.

Como vemos, aqui opera numa rede de relações sociais e poder que dá sentido à prestação de serviços para a "comunidade". Como os becos e vielas são muito estreitos só as motos oferecem uma flexibilização para dar um conforto àqueles (as) que moram nas partes mais inóspitas da favela. Muitos idosos ganharam autonomia social e econômica com o serviço de moto-táxis. Hoje, eles podem não só subir e descer aos pontos mais comerciais da favela, como suas compras são entregues na sua porta por moto-táxis independentemente de onde moram. E mais, os moto-táxis deixam as compras na porta, no meio dos becos ou vielas, e ninguém mexe. O idoso pode fazer outras coisas porque suas compras estarão "seguras", mesmo expostas na rua. Num depoimento colhido de um pequeño comerciante de um complexo de favelas importante do Rio de Janeiro ele afirma que ao precisar se ausentar de seu negócio costumava deixar as encomendas feitas por seus clientes numa gaveta em que eles podiam recolher o objeto de serviço e colocar o dinheiro de pagamento na mesma gaveta, inclusive fazendo troco, se necessário!

\section{A lógica ambígua das relações sociais no mercado de trabalho na favela}

A experiência no cotidiano da favela permite-nos dialogar com pessoas e não somente ver, mas entre-ver algumas lógicas das relações de trabalho que são distintas daquelas a que estamos acostumados a ver no mercado oficial de oferta de emprego. Tais lógicas vão de encontro à formação do exército de reserva, criado pela lógica do capitalismo, e o dilui numa rede de pseudo-solidariedade que, na situação a seguir narrada, será vista num setor da economia da favela sob a regulação do tráfico. A situação narrada a seguir só foi possível através de uma experiência de participaçãoobservante em uma das mais importantes favelas do Rio de Janeiro.

Waldemar, nome obviamente fictício aqui atribuído em homenagem a Wilson Batista, era um trabalhador comum, que até os 42 anos de idade, aproximadamente, atuou na área de segurança de boates e de empresas do setor financeiro. Era negro, faixa preta de jiu-jitsu e, quando jovem, mantinha o corpo num padrão aceitável pela estética exigida pelo mercado oficial. Ressalte-se que na lógica deste mercado não basta as habilidades e competências para o exercício do cargo posto que é exigido, também, um corpo modelizado do trabalhador, pois este passa a ser propriedade alheia sendo, inclusive, usado como manequim no portfólio das empresas.

Num determinado dia Waldemar nos falou sobre as dificuldades de encontrar emprego. Disse que estava desempregado e "passando um sufoco" para sustentar a sua família. Segundo ele, mesmo "correndo atrás” de emprego lá fora, referia-se ao espaço fora da favela, estava muito difícil. Sua esperança era uma oportunidade que soubera estar por se abrir na própria 
favela. Tratava-se da contratação de seguranças para "vigiar" as agências bancárias instaladas dentro da favela. Perguntado se teria a carteira assinada pelas agências ou se seria terceirizado hesitou um pouco para dar a resposta, porém disse que o pagamento seria feito através de uma parceria entre as agências bancárias e outros comerciantes locais.

É importante situar o leitor no contexto espaço-temporal em que esses fatos estavam ocorrendo. Na favela em questão, várias tentativas de assaltos passaram a ocorrer contra as agências bancárias e aos estabelecimentos comerciais de maior porte como, por exemplo, as agências da rede Bob’s e da Deplá. À época estava em curso uma operação policial denominada "Operação Asfixia" cujos efeitos na favela em questão foi o aumento dessas tentativas de assalto, segundo muitos moradores. Essa versão dava conta de uma compreensão da geografia política da violência na cidade por parte dos moradores que viam a "Operação Asfixia" como sendo um acordo entre a polícia e um outro “comando” de traficantes que negociavam o controle de território e a divisão dos lucros, em que tais assaltos passaram a ser um recurso para obtenção de dinheiro que sustentasse por um tempo o “comando" atingido, nas proximidades da Zona Sul da cidade.

Para dar conta do problema, os traficantes da favela em questão em diálogo com os comerciantes de maior porte e com as agências bancárias decidiram implantar um sistema de segurança próprio, "dichavado" ${ }^{27}$ segundo sua linguagem. Passaram a contratar moradores desempregados o que incluiu a possibilidade de retorno ao mercado de trabalho Waldemar, até porque tinha experiência em segurança de estabelecimentos financeiros. Aos jovens diretamente ligados ao tráfico que estivessem dispostos a fazer dupla jornada de trabalho, isto é, virar à noite trabalhando na boca-defumo e durante o dia continuar como segurança também era oferecida a oportunidade de ampliar seus ganhos na nova área de atuação de proteção às agências bancárias e outras firmas do circuito superior que ali operam. Duas modalidades de regime de contratação, portanto.

Com isso, os traficantes demonstravam não somente o poder de controle, mas se legitimavam impondo uma lógica de regulação do território que, ao mesmo tempo, consolidava uma territorialidade paralela à lógica legal oferecendo segurança às agências bancárias e aos grandes comerciantes ali estabelecidos. Legitimava-se, também, uma experiência de empregabilidade num contexto social em que as possibilidades de emprego são pequenas e, normalmente, as mais precárias.

Uma das exigências feitas no acordo era a de que os seguranças, nesse caso incluem-se todas as categorias acima mencionadas, não portariam as suas armas de forma ostensiva. Assim, eles as guardavam embaixo de carros estacionados próximos aos locais de proteção, nas lixeiras, e em algunas brechas entre "barracos". Tais exigências fundamentavam-se numa lógica de limpeza moral visto que os locais a serem protegidos eram a Caixa Econômica Federal, o Banco Itaú e, onde, hoje, funciona uma agência do Bradesco. 
Logo após a instalação desse sistema de segurança ocorreram alguns assaltos que não puderam ser previstos nem evitados. Até que, com o aperfeiçoamento da estrutura de funcionamento, numa determinada ocasito os assaltantes foram surpreendidos no ato de sua investida. Houve troca de tiros e perseguição dentro da favela. Como os seguranças do sistema recémimplantado não deram conta da tarefa, outro contingente foi acionado. Convocaram os bandidos que estavam, naquele momento, em horário de trabalho na boca-de-fumo. Isso fez com que Waldemar, um dos seguranças contratados na categoria de segurança formal desempregado com experiência, abandonasse a missão de perseguir os assaltantes.

Logo depois do fim da operação, em que "um dos assaltantes foi pego e levado ao tribunal da favela, onde foi executado com a pena de morte”, segundo um morador da favela, os bandidos que participaram da operação se voltaram para Waldemar que havia abandonado a missão-função de trabalho. A cena foi cinematográfica. Os bandidos da ativa interrogaram Waldemar publicamente, na rua, diante de todos os comerciantes próximos e dos transeuntes atentos aos movimentos da favela. O agrediram com insultos e tapas.

O curioso é que em sua defesa Waldemar argumentava, desesperado, que se retirou da ação porque pensou que a bandidagem tinha assumido a missão. Um dos bandidos gritava, perguntando: "E tu, é o que? Tu não é bandido? Quem é que te paga? Waldemar respondia: "Não, não sou bandido! Fui contratado para fazer a segurança da Caixa Econômica”.

Essa ambivalência demonstra factualmente a crueldade do que estamos chamando de capitalismo para-legal que, como vemos, compõem com o capitalismo "legal". Waldemar havia sido dispensado do mercado formal, pois nem seu vigor nem seu corpo serviam mais às agências a quem serviu durante sua juventude. Agora, era mais um na estatística do exército de eserva. No entanto, a subjetividade que regia a sua matriz de ação era a da oficialidade.

Evidencia-se, assim, a existência de um tipo de lógica da favela que, embora incorpore outras lógicas disponíveis no seu sistema de socialidade particular, também desenvolve formas cruéis de descartar o trabalhador quando este não serve para seu sistema. Isso impõe a criação de outras subjetividades, em relação ao sentido do emprego que esbarra na invenção de moralidades possíveis nas circunstâncias de opressão que estão submetidos, por exemplo, os desempregados da favela, na geração da própria subsistência.

A favela é um espaço de tal magnitude para as experiências de seres humanos que vivem nos limites da opressão, que as interações sociais, econômicas, políticas e culturais ganham especificidades, pautadas em táticas circunstanciais de sobrevivência no atual capitalismo. Isso possibilita a invenção de lógicas de ação multiplicáveis, pois são imitáveis. Assim, as especificidades deixam de ser singularidades e passam a configurar-se como 
experiências que se expandem através dos circuitos de comunicação dos moradores de favela, tais como os transportes alternativos e os bailes funks oferecidos pelos traficantes.

As relações entre o "circuito superior" e o "circuito inferior" da economia, como lhes chamou Milton Santos, são aqui mais do que explícitas. Nomes como Depla, Bob’s, Caixa Econômica Federal, Itaú e Bradesco podem ser vistos nos anúncios comerciais até mesmo no horário nobre da televisão. Todavia, no espaço da favela a segurança dessas empresas negocia com o poder de fato e não raro a mediação é feita pelas forças policiais oficiais. Afinal, como disse Luiz Eduardo Soares, a tolerância diante da venda de serviços de segurança por parte de policiais civis e militares tem favorecido esse mercado em expansão. Em consonância com isso, a relativa liberação do uso de entorpecentes ilegais, segundo a nova lei, tem aumentado o mercado de drogas e, mesmo que a legislação se pretenda mais rigorosa para com os traficantes, a resultante é aumentar o poder do policial na intermediação desse mercado da insegurança para vender segurança também em expansão. As relações do para-capitalismo com o capitalismo estão longe de ser eventuais, são orgânicas.

Enfim, a dinâmica do capitalismo engendra uma geografia desigual onde dois circuitos se configuram onde a favela é o lócus de reprodução/ invenção dos mais explorados entre os explorados (Casanova, 1971). Há um capitalismo para-legal nas favelas ${ }^{28}$, que não permite aos brasileiros (e latino-americanos) mais pobres a inatividade e a morte social, ao contrário, onde muitos são da ativa desse exército de reserva. Parte desse capitalismo para-legal deu novas formas ao que Milton Santos identificara como "circuito inferior” da economia da cidade, da sociedade.

\section{As feiras nas favelas. Livres?}
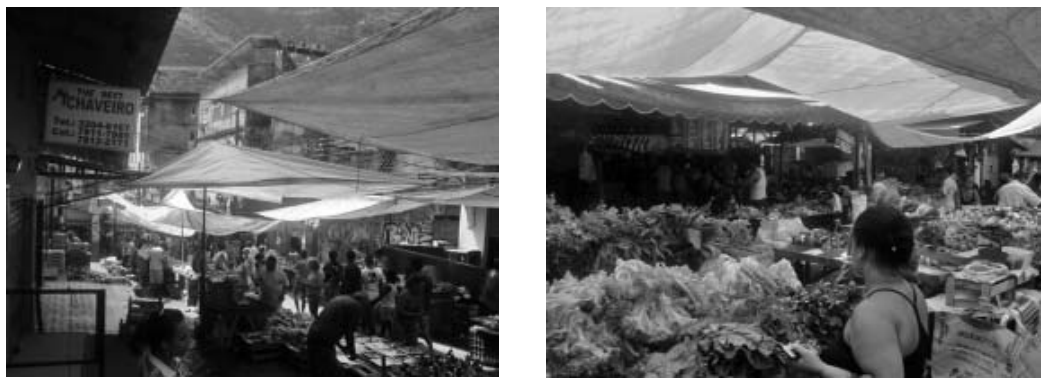

Se já havia um circuito com dinâmica própria nesses espaços urbanos que Milton Santos tratou com os recursos teóricos disponíveis de uma economia política do espaço dos anos setenta, a relativa autonomia desses circuitos passou a ter uma dinâmica política que enseja sua compreensão através da família de conceitos em torno do território o que implica o processo de territorialização e as territorialidades. Todavia, muito do que 
Milton Santos analisou quanto às relações entre o circuito superior e o circuito inferior permanecem análises extremamente atuais, como apontamos a seguir nas considerações finais deste artigo. Chico de Oliveira em seu clássico “Crítica à Razão Dualista” também já havia nos alertado para o fato de que a acumulação primitiva do capital não era algo que remetia às origens do capitalismo, mas que lhe era estrutural. O que não havia sido referido é que a favela é locus dessa acumulação primitiva aqui e agora.

Milton Santos nos alertou contra qualquer romantismo sobre o significado dessa realidade complexa onde criativamente os pobres se vêem constrangidos a inventar suas vidas. Alertou-nos do perigo de aceitar a tese de Joan Robinson (1962) quando diz que "a desgraça de ser explorado por capitalistas não é nada comparada à desgraça de não ser explorado de nenhuma maneira”. "Naturalmente, o circuito inferior poderia ser definido como um sistema, e nós já o fizemos (Santos, 1971). Todavia, deixando de levar em conta os níveis de decisão ou a escala, como condição epistemológica fundamental para permitir a divisão de uma totalidade, a verdade pode ser escamoteada. É por essa razão que não pode haver nenhum setor informal dentro de uma sociedade formal global. $\mathrm{O}$ todo é dirigido pelo mesmo sistema de normas. Ainda que o sistema inferior seja dinâmico, seu dinamismo é dependente. Desse modo, não pode ser objeto de análise ou de planejamento que não levem em conta o dinamismo que caracteriza o outro circuito dentro de uma economia que também é dependente”. (...) “A eliminação da situação de dependência do circuito inferior em relação ao circuito superior só será possível com uma mudanza estrutural. O ideal, evidentemente, seria que "o circuito inferior se tornasse menos inferior, mas isso só poderia ser feito se o circuito superior se tornasse menos superior”. Do contrário a situação de dependência continuará e até se agravará, embora sob formas diferentes”. (Santos, 1978: 57-58).

Não se combate esse capitalismo para-legal somente nas favelas. Ele não é específico das favelas, sabemos. Enquanto houver paraísos fiscais, territórios que são irmãos gêmeos dos territórios sem controle do estado comandados por para-empresários das drogas nas favelas, haverá possibilidade de lavar dinheiro de todos os para-empresários tão bem distribuídos em toda a cadeia de poder da sociedade. Talvez assim possamos começar a entender parte do que se chama candidamente de impunidade, palavra que esconde e revela ao mesmo tempo porque não se pune. O não punir é o modo de funcionamento dessas relações sociais e de poder que nos constitui e, assim, a impunidade é um conceito cientificamente vazio, embora moralmente pleno de sentido ${ }^{29}$.

Na favela, a lógica do pavor não é somente posta em prática pelos bandidos, pois está imbricada no sistema de poder junto com empresas, ONGs e policiais. Como estratégia de afastamento e controle de qualquer possibilidade de integração “os donos do poder” criam normatizações compulsórias, que atendem apenas às lógicas dos criadores. No entanto, essas estratégias criam um lugar de poder forte, mas não totalizador, pois inerente à sua criação está a contra-criação das táticas que embora não 
criem um lugar de poder, visto que são caracteristicamente circunstanciais e nascem nas entranhas das estratégias, impõe ao jogo de disputas imprevisibilidades. Tais imprevisibilidades são oriundas de racionalidades paralelas que se forjam a partir das inteligências aguçadas pelas situaçõeslimites de sobrevivência na cidade. Sugerimos, que há um outro pavor que se instala hoje nas favelas sob a mira da "pacificação" e que não é somente o pavor do banho de sangue que sempre está no ar, sempre como estratégia de combate, mas também as normatizações que vem à reboque desse processo. Os moradores de favelas, como pudemos demonstrar no presente artigo, desenvolvem suas lógicas de uso dos espaços e suas relações com a cidade dentro de um mínimo espaço citadino conquistado-construído nas brechas das estratégias. Ao invés da lógica do esquadrinhamento cartesiano, geometrizado, imposto pela "cidade moderna", os favelados do Rio de Janeiro expandiram e complexificaram as lógicas e tecnologias dos povos originários indígenas e dos povos negros africanos, misturando-as na resistente "panela de barro" nordestina, que resiste bravamente ao fogo. A partir daí, a sinuosidade dos becos e vielas se fizeram alternativas aos esquadrinhamentos matematizados da cidade normatizada. Às ruas projetadas a priori, se fizeram os becos pensados a partir das circunstâncias dos usuários da favela, dos praticantes do lugar. A prioridade da ocupação não era o projeto futuro de funcionalidade ou de estética, mas a integração, no presente, daqueles que precisavam compartilhar a cidade. Assim, a partir da lógica dos becos, da sinuosidade, e não do esquadrinhamento, a favela se fez, se faz, e se refaz taticamente em resposta aos históricos e constantes investimentos estratégicos das lógicas normatizadoras, que visam a eliminação desse "Outro" da cidade. Nesse sentido, e para não concluir, mas, ao contrário, incitar a permanência do debate, sugerimos, ainda que hipoteticamente, que apavora os moradores das favelas-alvo da "pacificação" não somente o medo da morte física, pois desta, já aprenderam forçadamente a lidar, mas do epistemicídio das suas racionalidades sinuosas que, historicamente, permitiram a sua presença em um dos maiores bens já produzido pela sociedade humana: a cidade. 


\section{Notas}

${ }^{1}$ Expectativa que, felizmente, não se confirmou em função, sobretudo de gestões intensas que buscavam uma saída que respeitasse os direitos humanos, onde se destacaram o Sr, José Junior, do AfroReggae, e o Deputado Marcelo Freixo, do PSOL. O Sr. Rodrigo Nascimento, exmembro do BOPE e atual comentarista de segurança da Rede Globo de Televisão, chegou a afirmar no ar que aqueles delinqüentes que batiam em retirada da Vila Cruzeiro em direção ao Complexo do Alemão fatalmente teriam sido metralhados e bombardeados se tivessem no Iraque ou no Afeganistão. Eis um pouco do clima de banho de sangue com que a mídia preparava a opinião pública para o massacre que se desenhava. Notícias divulgadas dias após os acontecimentos davam conta de que o secretário de Segurança do estado do Rio de Janeiro, Sr. Beltrame, admitia que a operação pudesse terminar de modo sangrento.

${ }^{2}$ Essa expressão inspira-se na distinção feita por lideranças de mulheres argentinas que se viram diante da situação limite de prostituir-se para sustentar suas famílias depois da crise de dezembro de 2001 (“Que se vayan todos”). Embora tendo que partilhar as mesmas circunstâncias opressivas das mulheres que praticam a prostituição há muitos anos, assim como muitas das mesmas lutas e reivindicações, essas mulheres se auto-identificavam não como prostitutas, mas como mulheres em situação de prostituição. Acreditamos que o mesmo seja válido para muitos desses jovens inseridos no mundo do tráfico. Agradecemos, em particular, a entrevista que nos foi concedida em janeiro de 2004 por Graciela Collante da Associação de Mulheres Argentinas pelos Direitos Humanos - AMMAR.

${ }^{3}$ E isso não é qualquer coisa haja vista a banalização desse conceito com sua apropriação por gestores estatais, de corporações transnacionais e instituições multilaterais, como o Banco Mundial em que o conceito vem sendo esvaziado da dimensão política que lhe é epistemicamente essencial. Para uma melhor análise ver Montenegro, 2006 e Hasbaert, Rogério 2004.

${ }^{4}$ Em grego, originariamente, polis é como se designava o muro que delimitava a cidade do campo. Portanto, polis é limite, muro. A palavra política guarda esse sentido originário de limite posto que, para os gregos, assim como para Hanna Arendt, é a arte de definir limites na pluralidade de indivíduos e sujeitos coletivos e, nesse último caso, afastamo-nos de Hanna Arendt, embora partilhando o mesmo sentido de liberdade como condição primeira da política.

${ }^{5}$ Sobre o tema da invisibilização do negro na ordem urbana ver Andrelino (Campos, 2005) que é o melhor livro que se produziu na geografia urbana brasileira sobre o tema.

${ }^{6} \mathrm{O}$ bairro de Madureira, na Zona da Central, é conhecido como um dos mais importantes redutos do samba. Ali se encontram as escolas de samba Império Serrano, Portela e Tradição.

${ }^{7}$ Há, na Rocinha, dois locais, um denominado Cesário, e, outro, chamado de Laboriaux onde havia uma represa conhecida como Caixa D’água dos Padres, já dentro da área de Mata Atlântica que mantém fortes marcas da presença e resistência de comunidades negras. No Cesário, tal marca é mantida através das narrativas e memórias dos moradores mais antigos. Na subárea do Laboriaux, até o início da década de 1990 ainda era possível encontrar correntes fincadas no chão. Atualmente está mais difícil verificar se ainda permanecem essas correntes, porque o tráfico transformou o lugar em rota de fuga e ocupa esse espaço que um dia foi área de lazer das crianças, onde se divertiam tomando banho na "piscina dos padres” com exclusividade. 
${ }^{8}$ Entre o Estácio e a Vila Isabel está o bairro da Tijuca e, nas adjacências, se concentram outras das mais importantes escolas de samba do Rio de Janeiro: Estácio, Unidos da Tijuca, Vila Isabel e Mangueira.

${ }^{9}$ Até hoje na Rocinha se mantém uma tradição, na feira local aos domingos, em que se reúnem vários nordestinos, e até mesmo turistas, em torno de dois repentistas que há décadas se afirmam disputando o espaço com a bandidagem, com as atividades dominicais das igrejas e, atualmente, com um ponto de moto-táxi. Na feira da Rocinha, a tradição se mantém pela força das disputas dos moradores nordestinos da favela que mesmo dentro de uma complexa rede de opressão e de imposição de padrões musicais-culturais “do morro", ressignificam sua nordestinidade mantendo com os próprios recursos, informalmente, aquele evento semanal há anos. Fotos: Rodrigo Torquato da Silva

${ }^{10}$ Observe-se que esse crescimento e expansão geográfica dos bairros proletários foi redesenhando a geografia da cultura popular, particularmente a do samba, como vemos na nova geografia das escolas de samba: Imperatriz Leopoldinense do bairro de Ramos, um dos bairros abrangidos pelo Complexo do Alemão; Caprichosos de Pilares, das imediações da Abolição e do Engenho de Dentro; Grande Rio, de Duque de Caxias; Beija Flor, de Nilópolis; Cubango, de Niterói e São Gonçalo; Porto da Pedra, de São Gonçalo; Viradouro, de Niterói, para nos restringirmos às escolas de samba que circulam pelo chamado grupo especial.

${ }^{11} 13$ É sintomático que um ex-presidente da Associação Brasileira de Cordelistas, o saudoso ator Rafael de Carvalho, fosse ágrafo. Não escrever pode ser também uma forma de resistência e o nordestino Rafael de Carvalho bem o sabia, pois era comunista. Observe que ágrafo não é o mesmo que analfabeto, pois o ágrafo sabe ler. Devemos a compreensão desse significado a um militante da FRETILIN - Frente Revolucionária de Timor-Leste Independente, o Sr. Roque, que também se auto-designava ágrafo.

${ }^{12}$ Pelego - pele de carneiro a que se deixa ainda aderente a lã. (...). Sentido popular e peyorativo - Denominação dada a membros de sindicatos que agiam sob inspiração do Ministério do Trabalho ou de políticos ditos trabalhistas. Consultar: http://www.dicio.com.br/ pelego.

${ }^{13}$ Ver a poesia Traficando Informação de MV Bill em http://letras.terra.com.br/mv-bill/ 80315/.

${ }^{14}$ Exibido em 25 de setembro de 2007, onde Mano Brown, principal líder do grupo, justifica a sua presença em função de "aquele programa ser importante e sério". Interessante observar que uma posição análoga foi tomada pelo antropólogo Luiz Eduardo Soares quando da megaoperação no Complexo do Alemão e da Vila Cruzeiro. O antropólogo colocou em seu blog que havia recebido 117 ligações telefônicas para falar sobre o que se passava. Afirma ter desligado o celular mesmo salientando suas tradicionais boas relações com a mídia. Diante da espetacularização em curso não via a mínima possibilidade de uma reflexão mais aprofundada. Todavia, no mesmo dia em que publicara em seu blog essas observações avança uma importante reflexão, de que nos aproveitamos nesse artigo e, à noite, aparecia no mesmo programa Roda Viva da TV Cultura. Roda Viva é um dos raros programas de entrevista ao vivo da televisão brasileira onde o entrevistado tem, no mínimo, uma hora e meia para expor suas idéias. Merece registro o fato de ser uma televisão pública e não comercial. 
${ }^{15} \mathrm{O}$ ator Rafael de Carvalho em depoimento pessoal declarara que a rima, na forma cantada dos versos dos cordelistas, é como se fossem as linhas da pauta de um caderno, pois ajuda a fixar as idéias, a memória. A imagem é tão precisa, quase uma imagem-coisa, como as de João Cabral de Melo Neto, se me permitem.

${ }^{16}$ Nessa eleição, setores da ditadura tentaram evitar a vitória de Leonel Brizola, numa articulação que envolveu a mídia e setores militares no famoso caso Proconsult denunciado então pelo Sr. Cesar Maia.

${ }^{17}$ Tenho em conta a existência de policiais honestos, que não são poucos, e que também são vítimas desse sistema perverso até porque estão ainda mais expostos aos que usam a mesma farda que eles e que sabem que são identificáveis. Portanto, não se trata de uma simples corregedoria que puna os policiais bandidos, pois se trata de um fenômeno sistêmico onde o próprio modo de funcionamento da estrutura policial é que é o problema. Como diz o sociólogo José Claudio de Sousa Alves: “Não estou dizendo que o Estado foi corrompido. Estou dizendo que o próprio estado em si é o crime. O mercado e o Estado são os grandes problemas da sociedade brasileira. O mercado de drogas, articulado com o mercado de segurança pública, com o mercado de tráfico de drogas, de roubo, com o próprio sistema financeiro brasileiro, é quem tem interesse em perpetuar tudo isso”. Ver Uma guerra pela regeografização do Rio de Janeiro. Entrevista especial Alves em http:// www.ihu.unisinos.br/index.php?option=com_noticias \&Itemid=18\&task =detalhe\&id=387 Consultado em 30/11/2010.

${ }^{18}$ Não é um acaso que esse jovem intelectual, Jonathan Marcelino, seja negro.

${ }^{19}$ Falo aqui de denúncias efetuadas pelo Subcomandante Matos, do EZLN, a los retenes do exército nacional mexicano que nos parava quando de viagem que um dos autores desse artigo, Carlos Walter Porto-Gonçalves, fez à região em novembro de 1997, a convite do EZLN. Diante do meu testemunho, em todos os retienes o Subcomandante Matos fez questão de que se registrasse a denúncia de que no Espiñazo del Diablo haviam pistas de pouso de aviões do narcotráfico e que a denúncia era do EZLN. E o fazia procurando desmentir que a razão pela qual aqueles retienes se constituíam era para combater los narcos. Ao contrário, aqueles retenes eram para combater o EZLN.

${ }^{20}$ Deixamos aqui explícita a ambigüidade do que significa sambar e dançar na gíria carioca que bem pode ser iludidos e/ou perdemos.

${ }^{21}$ Fala-se de mais de 1200 favelas no Rio de Janeiro ou de aproximadamente 300 complexos de favelas. Treze UPPs é, na verdade, uma demonstração do caráter epidérmico da nova política que vem sendo posta em prática.

${ }^{22}$ Aliás, esses objetos de comunicação e de transportes, como os celulares e as motos, vêm tendo múltiplos usos por parte dessas populações pobres, inclusive usos políticos. Foi o que vimos na Venezuela, em 2002, quando a flexibilidade, velocidade e capilaridade desses objetos móveis e moventes mobilizaram os pobres dos cerros de Caracas para descerem e cercarem o Palácio Miraflores acuando os golpistas que intentavam um golpe de estado. A ordem democrática foi restabelecida dando respaldo popular à unânime condenação do golpe por parte dos chefes de estado da América Latina, inclusive do então presidente Fernando Henrique Cardoso.

${ }^{23}$ Um negro sabe que não pode olhar para dentro de uma agência bancária à procura de um 
amigo, por exemplo. Sabe que será visto como suspeito. O saber/sabor do racismo está incorporado. O corpo fala.

${ }^{24}$ Pesquisa realizada pelo LEMTO-UFF e pelo GeoAgrária-UERJ com dados da CPT dão conta de que entre 2003 e 2006 temos a maior média anual de famílias expulsas e de familias despejadas no Brasil do campo brasileiro, a maior média anual de todo o período histórico desde que a CPT acompanha esses conflitos, ou seja, desde 1985 (Porto-Gonçalves, C.W. e Alentejano, P. R. A. 2010).

${ }^{25}$ Cavalo tanto pode ser o animal de monta como, na linguagem da umbanda, o corpo que recebe um espírito.

${ }^{26}$ Para entrar na favela há que respeitar sua lógica própria. A visita de um político, seja ele governador ou presidente, e não falamos de hipóteses, é precedida de intensas e tensas negociações para saber quem vai fazer a "segurança”. Há uma geografia política complexa de facções e de milícias no controle de cada território e a eventual visita de uma autoridade deixa sempre aberta a possibilidade de perda de controle pela presença de uma autoridade eventual. Não se constrói um teleférico, como o do Complexo do Alemão, sem negociar com a facção local. E as obras podem ter seu projeto adequado às finalidades múltiplas, inclusive a de garantir rotas de fuga.

${ }^{27}$ Gíria que nesse contexto pode ser lida como disfarçado.

${ }^{28} \mathrm{O}$ capitalismo para-legal não se restringe ao mundo das favelas. Há outros, sabemos, que passam pela corrupção feita por para-empresários de empreiteiras, para-empresários do setor de telefonia, para-empresários do setor de marketing e publicidade que fazem a mediação com a mídia e com políticos nos caixa 2 de campanha eleitoral, os para-empresários do capital bancário-financeiro, desaguadouro onde se destinam os lucros de todas essas atividades.

${ }^{29}$ Aqui não há como deixar de lembrar do diálogo do filme Giordano Bruno de Giuliano Montaldo, quando depois da quarentena na inquisição sobre sua pregação junto aos reis e aos poderosos para acabar com a opressão, Bruno (1548-1600) diz que seu erro, depois de muita reflexão, foi “ter pedido aos opressores para acabar com a opressão". 


\section{Bibliografia}

Aalvito, Marcos (2001), As cores de Acari: uma favela carioca. Editora FGV, Rio de Janeiro.

Arendt, Hannah (1981) A Condição Humana. Tradução de Roberto Raposo, Forense Universitária, Rio de Janeiro.

Campos, Andrelino (2005), Do Quilombo à Favela, Editora Bertrand, Rio de Janeiro.

Casanova, Pablo González (1971), Sociología de la Explotación. Ed. Siglo XXI, México.

Castro, Iná (org) (2006), Geografia: Conceitos e temas. RJ. Bertrand, Brasil.

Harvey, Davis (2005), O Novo Imperialismo. Ed. Loyola, São Paulo.

Hasbaert, Rogério (2004), O Mito da (des)territorialização. Ed. Bertrand, Rio de Janeiro.

Leitão, Gerônimo (2009), Dos barracos de madeira aos prédios de quitinetes: uma análise do processo de produção da moradia na favela da Rocinha, ao longo de cinqüenta anos. Ed. UFF, Niterói-RJ.

Machado da Silva, Luiz Antônio (2008) Vida sob cerco: violência e rotina nas favelas do Rio de Janeiro. Ed. Nova Fronteira, Rio de Janeiro.

Montenegro, Jorge (2006) Desenvolvimento em (Des)construção: Narrativas escalares sobre desenvolvimento territorial rural. Tese doutoral apresentada ao Programa de Pós-Graduação em Geografia da Faculdade de Ciências e Tecnologia da Universidade Estadual Paulista, Campus de Presidente Prudente.

Paiva, Vanilda (2000) A “Contemporaneidade do não coetâneo": emergência de uma nova era e sociedade do conhecimento. Seminário “Educação de Adultos da Perspectiva da Educação Permanente” promovido pelo OREALC/UNESCO e Ministério da Educação do Chile, Santiago.

Porto-Gonçalves, Carlos Walter (2003), “A Geograficidade do social: uma contribuição para o debate metodológico sobre estudo de conflito e movimentos sociais na América Latina”. In Seone, José (Comp.) Movimientos sociales y conflito em América Latina. Ed. Clacso, Buenos Aires.

Ídem (2001), Geo-grafías: movimientos sociales, nuevas territorialidades y sustentabilidad. Ed. Siglo XXI, México.

Porto-Gonçalves, Carlos Walter e Alentejano, Paulo Roberto (2010), “O agronegócio e a perpetuação da violência no campo brasileiro: reafirman- 
do o latifúndio moderno-colonial”. In Cadernos de Conflitos 2009, Ed. CPT, Goiânia.

Ribeiro, Ana Clara Torres (2008), “Cidade e capitalismo periférico: em direção à experiência popular”. Revista Margem Esquerda, v. 12, p. 25-31, Rio de Janeiro.

Santos, Milton (1987), O Espaço do Cidadão. Ed. Nobel, São Paulo.

Ídem (1982), Pensando o espaço do homem. Ed. Hucitec, São Paulo.

Ídem (1980), A Urbanização Desigual. Ed. Vozes, Petrópolis-RJ.

Ídem (1979), Espaço e Sociedade. Ed. Vozes, Petrópolis-RJ.

Ídem (1979), Economia Espacial: Críticas e Alternativas. Ed. Hucitec, São Paulo.

Ídem (1978), Pobreza Urbana. Ed. Hucitec, São Paulo.

Ídem (2004) [1975], O Espaço Dividido. os dois circuitos da economia urbana dos países subdesenvolvidos. São Paulo: EDUSP; 2a edição.

Ídem (1971), “L'économie pauvre des Villes de pays sous-développés”. Les Cahies d'Outre Mer 24 (94): 105-122.

Ídem (1965), A cidade nos Países Subdesenvolvidos. Ed. Civilização Brasileira, Rio de Janeiro.

Souza, Marcelo Lopes de (2010), A “reconquista do território” ou: Um novo capítulo na militarização da questão urbana. Consultado em 12/-1/ 2011. http://fragmentosativos.wordpress.com/2010/12/06/a\%E2\%80\%9Creconquista-do-territorio\%E2\%80\%9D-ou-um-novo-capitulo-na-militarizacao-da-questao-urbana/

Ídem (2006), “O território: sobre espaço e poder, autonomia e desenvolvimento”. In: Castro, Iná (org). Geografia: Conceitos e temas. RJ. Bertrand, Brasil.

Silva, Jailson de Souza e Barbosa, Jorge Luiz (2005), Favela: alegria e dor na cidade. Ed. SENAC, Rio de Janeiro.

Silva, Rodrigo Torquato da (2010), Escola-favela e Favela-escola: "Esse menino não tem jeito!” Tese doutoral apresentada ao Programa de PósGraduação em Educação na Universidade Federal Fluminense, Campus Gragoatá, Niterói-RJ.

Thompson, Edward P. (1987), [1963], A formação da classe operária inglesa. Paz \& Terra, Rio de Janeiro. 
Polis, Revista de la Universidad Bolivariana, Volumen 10, $N^{\circ}$ 28, 2011

Varal de Lembranças (1983), “Histórias da Rocinha”. União PróMelhoramentos da Rocinha: Tempo e Presença, SEC; MEC; FNDE, Rio de Janeiro.

Vesentini, José William (1996), A Capital da Geopolítica. Ed. Ática, São Paulo.

Vianna, Letícia (2001), Bezerra da Silva: produto do morro: trajetória e obra de um cambista que não é santo. Ed. Jorge Zahar, Rio de Janeiro.

Zaluar, Alba (2004) Integração perversa: pobreza e tráfico de drogas. Ed. FGV, Rio de Janeiro.

Zaluar, Alba e Alvito, Marcos (2004), (orgs.) Um século de favela. 4 ed., Ed. FGV, Rio de Janeiro. 